\title{
GROUNDWATERS OF SERBIAN AND SLOVENIAN DINARIC KARST - COMPARISON OF CURRENT STATUS, USE, PROTECTION AND PERSPECTIVES
}

\author{
PODZEMNE VODE DINARSKEGA KRASA V SRBIJI IN SLOVENIJI \\ - PRIMERJAVA TRENUTNEGA STANJA, IZRABE, VAROVANJA \\ IN POTENCIALA
}

\author{
Dejan MILENIĆ1 \& Metka PETRIČ ${ }^{2}$
}

\begin{abstract}
UDC 556.34(497.1+497.4)

Dejan Milenić \& Metka Petrič: Groundwaters of Serbian and Slovenian Dinaric karst - Comparison of current status, use, protection and perspectives.

The Dinaric karst is the largest continuous karstland in Europe. With its outermost northwestern and eastern parts it extends to the territory of Slovenia and Serbia. Karst aquifers within it are very important sources of water supply in the two countries. We therefore decided to compare the characteristics of karst water resources and the approaches to the exploitation and protection of karst aquifers with the aim of searching for the most convenient methods for their research and management. Different characteristics of the two compared areas were established, as well as differences and similarities in the application of various research methods and the management approaches. The findings were summarized in the table which includes the most important parameters of karst water systems and research methods used for their study in the area of Dinaric karst in Serbia and Slovenia. As an example of good practice, two case studies are described in the article. For the Slovene part, vast experiences in the application of tracer tests with artificial tracers are reviewed and the guidelines for its efficient use in the research of karst aquifers are summarized. For the Serbian part, described case study of the detection of the pollution source in the recharge area of an important water source and the preparation of remedial measures are presented as an efficient approach to solve such problems on karst areas.

Keywords: karst water resources, groundwater quantity and quality, research methods.
\end{abstract}

Izvleček

UDK 556.34(497.1+497.4)

Dejan Milenić \& Metka Petrič: Podzemne vode Dinarskega krasa $v$ Srbiji in Sloveniji - primerjava trenutnega stanja, izrabe, varovanja in potenciala.

Dinarski kras je največje zvezno kraško območje v Evropi. S svojim skrajnim severozahodnim in vzhodnim robom sega na območje Slovenije in Srbije. Kraški vodonosniki znotraj njega predstavljajo pomemben vodni vir $\mathrm{v}$ obeh državah, zato smo se s ciljem iskanja najboljših rešitev pri njihovem raziskovanju ter načrtovanju izrabe in varovanja odločili za primerjavo značilnosti kraških vodnih virov in pristopov $\mathrm{k}$ upravljanju s kraškimi vodonosniki. Pokazale so se različne značilnosti kraških vodonosnikov, ugotovljene pa so bile razlike in podobnosti pri uporabi raziskovalnih metod, načinih izrabe in varovanja. Ugotovitve smo povzeli v tabeli, ki vključuje najpomembnejše parametre kraških vodonosnih sistemov in raziskovalne metode, ki se pri njihovem proučevanju uporabljajo na območju Dinarskega krasa v Srbiji in Sloveniji. Kot primer dobre prakse je v članku za vsako študijsko območje predstavljen po en študijski primer. V slovenskem delu je na osnovi bogatih izkušenj s sledilnimi poskusi z umetnimi sledili izpostavljen pomen te raziskovalne metode za raziskovanje kraških vodonosnikov, povzete pa so tudi smernice za njihovo bolj učinkovito uporabo. V srbskem prispevku opisana študija odkrivanja vira onesnaženja $\mathrm{v}$ zaledju pomembnega vodnega vira in izdelave predloga njegove sanacije predstavlja primer učinkovitega pristopa $\mathrm{k}$ reševanju tovrstnih problemov na kraških območjih.

Ključne besede: kraški vodni viri, količina in kakovost podzemne vode, raziskovalne metode.

\footnotetext{
${ }^{1}$ University of Belgrade, Faculty of Mining \& Geology, Dept. of Hydrogeology, Djusina 7, 11000 Belgrade, Serbia, e-mail:dmilenic@yahoo.ie

${ }^{2}$ Karst Research Institute SRC SASA, Titov trg 2, SI-6230 Postojna, Slovenia, e-mail: petric@zrc-sazu.si

Received/Prejeto: 28.04.2009
} 


\section{THE AIM, THE PURPOSE AND METHODOLOGY OF CARRIED OUT INVESTIGATION}

The European Union has declared groundwater resources to be a strategic mineral resource in $21^{\text {st }}$ century, and their protection and sustainable usage, in the way that basic balance values and reserves for future are not endangered, to be of extreme significance for the strategic development of the union. At he same time the USA are spending $70 \%$ of the budget proposed for geology on hydrogeologic investigations (groundwater investigations). Consequently, the investigation of the role and significance of groundwater resources in $21^{\text {st }}$ century is of strategic interest for each community.

Special attention is paid to identification, monitoring and protection of zones and regions rich in qualitative groundwaters, as well as, their controlled and sustainable usage. The Dinarides of the Balkan Peninsula are such regions. The Republic of Serbia and the Republic of Slovenia are countries with bordering east and northwest distribution of the Dinarides. Both states recognise scientific, professional, as well as other significance of investigations and evaluation of groundwater resources in Dinaric karst, which is testified by several projects targeting the mentioned problems. The aim of this paper is, that after two years of common investigations within the Agreement on scientific cooperation between Scientific Research Centre of the Slovenian Academy of Sciences and Arts (SRC SASA), University of Nova Gorica and
Faculty of Mining and Geology - University in Belgrade, take into account the investigations carried out so far, to recognize and evaluate current status of groundwater and give potentials and perspectives for further sustainable development of these resources.

In order to realise such a complex topic and make analogous comparisons and conclusions the correct investigation methodology was required. It was being developed in two directions:

1. development of general methodology of resource comparisons in their relatively uneven proportions in these two states, and

2. the development of particular methodology of regional and detailed karst aquifer investigations (Tab. 1; modified after Milenić 2004).

The selected study areas shown in this paper were classified and compared according to the degree and source of usage, the level of protection and potential.

Additionally, two particular case studies of karst investigations emphasise some specific problems and solutions used in the two countries:

1. In Slovenia - Examples of the use of tracer tests in hydrogeological researches on karst.

2. In Serbia - Environmental impact of sawmill by-products degradation-karst groundwater pollution case study, Western Serbia.

\section{GENERAL CHARACTERISTICS OF THE DINARIDES AND THE STUDY AREAS IN SER- BIA AND SLOVENIA}

The Dinarides take their name from Dinara Mountain at the Croatian-Bosnian border. They occupy the western part of the Balkan Peninsula from Slovenia, across Croatia, Bosnia and Herzegovina, Montenegro, Serbia, and Albania. The area is about $600 \mathrm{~km}$ long and over $200 \mathrm{~km}$ wide, covering approximately $60,000 \mathrm{~km}^{2}$, forming the largest continuous karstland in Europe (Kranjc 2004).

Tab. 1: Basic data for Serbia and Slovenia and the study areas.

\begin{tabular}{|l|c|c|}
\hline & Serbia & Slovenia \\
\hline Total area & $88,361 \mathrm{~km}^{2}$ & $20,273 \mathrm{~km}^{2}$ \\
\hline Total number of inhabitants & $\sim 9,396,400$ & $\sim 2,053,500$ \\
\hline Area of Dinarides & $\sim 27,000 \mathrm{~km}^{2}$ & $\sim 5,700 \mathrm{~km}^{2}$ \\
\hline$\%$ of total area & $\sim 30 \%$ & $\sim 28 \%$ \\
\hline No. of municipalities & 61 & 43 \\
\hline
\end{tabular}
western and eastern borders of the Dinarides (Fig. 2). Even though different in the total area, the proportions of the Dinarides in the two countries are similar (Tab. 1), which makes possible a relevant comparison.

In the further comparison, the emphasis is on the area of the Dinaric karst in the two countries. In spite of the high amount of precipitation, there are only a few surface streams on the $\mathrm{Di}$ naric karst. However, there are a few large rivers, with enough water to cut canyons through limestone belts. Sinking rivers, flowing underground from one karst polje to another, are very common. Extensive karst plateaux recharge large karst 


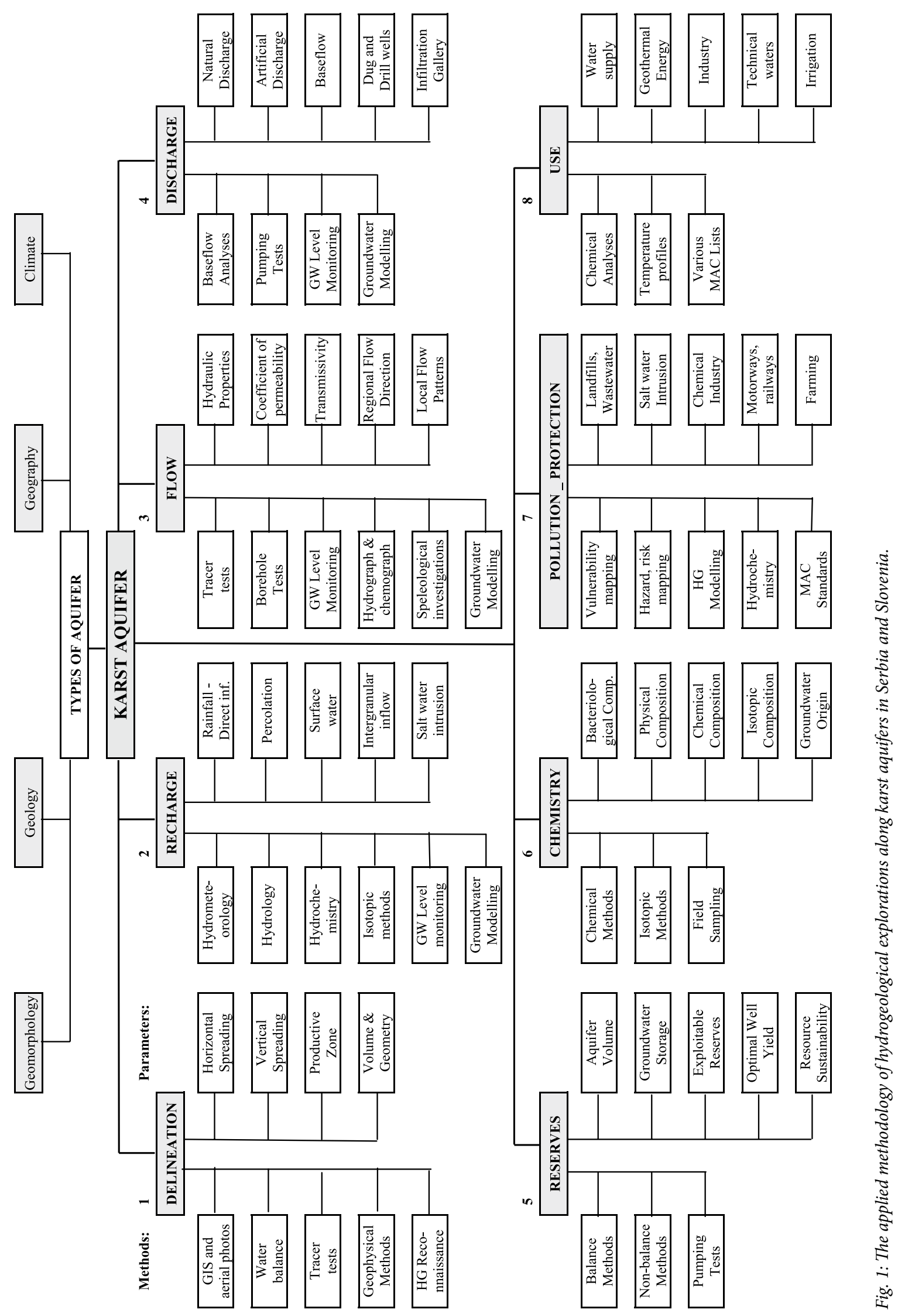




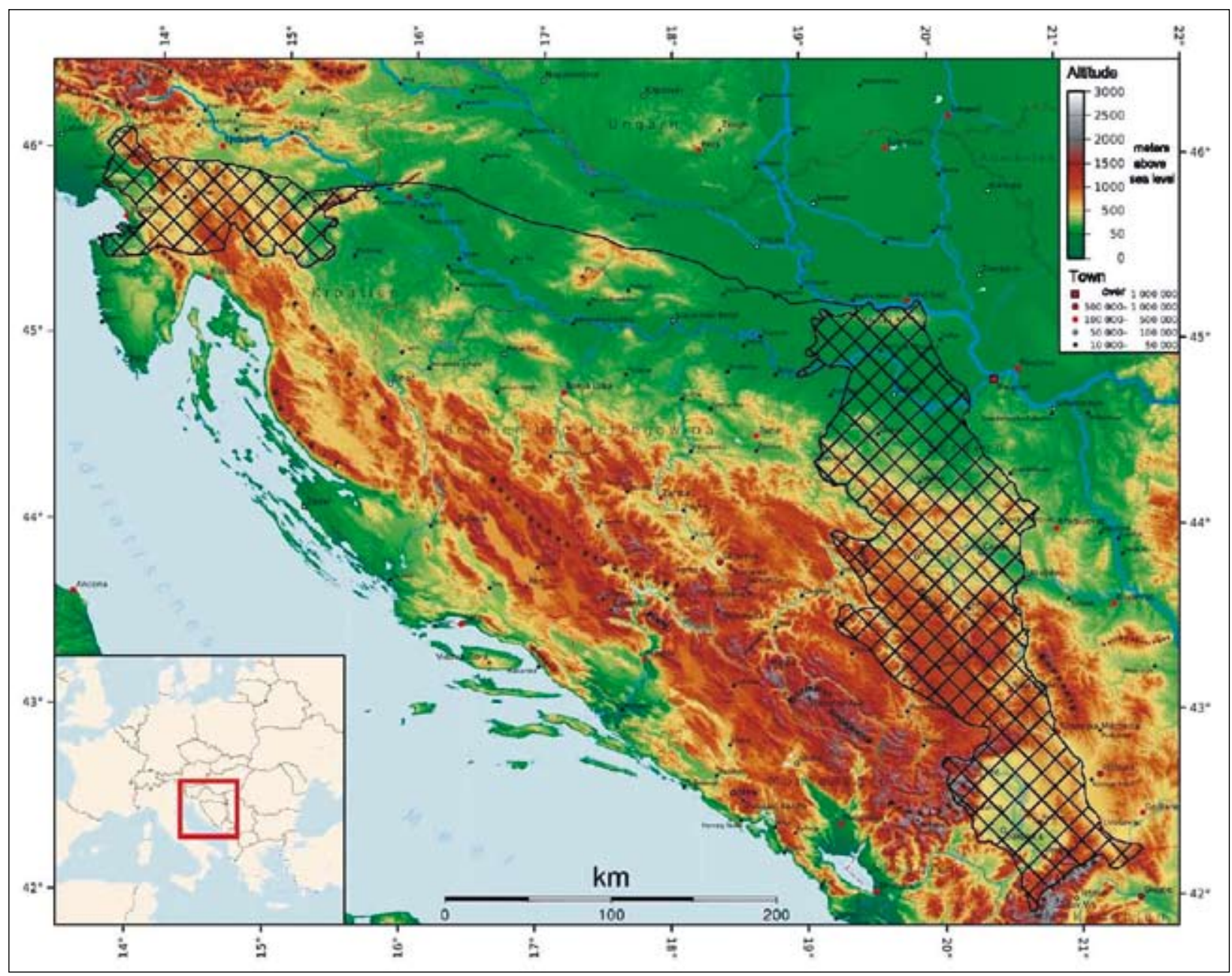

Fig. 2: Geographical setting of the Dinarides (the black line represents their outermost northern border), and the study areas in Serbia and Slovenia (criss-crossed areas).

Tab. 2: Basic climatic parameters for the Dinarides of Serbia and Slovenia.

\begin{tabular}{|l|c|c|}
\hline & Serbia & Slovenia \\
\hline No. of synoptic stations & 8 & 18 \\
\hline Type of climate & $\begin{array}{c}\text { Continental to } \\
\text { Continental-Alpine }\end{array}$ & $\begin{array}{c}\text { Mediterranean, } \\
\text { Continental, Alpine }\end{array}$ \\
\hline $\begin{array}{c}\text { Precipitation: annual average } \\
\text { max. annual amount }\end{array}$ & $623-966 \mathrm{~mm}$ & $1,000-3,200 \mathrm{~mm}$ \\
\hline Temperature: annual average & $1,664 \mathrm{~mm}$ & $3,758 \mathrm{~mm}$ \\
extreme T: $\mathrm{min} / \mathrm{max}$ & $6-12^{\circ} \mathrm{C}$ & $4-12^{\circ} \mathrm{C}$ \\
\hline
\end{tabular}

springs at the foothills. Along the Adriatic coast, water often flows directly into the sea via submarine springs or to springs on or near the coast (Kranjc 2004). For the comparison, some basic meteorological, hydrological and geomorfological parameters for the Dinaric karst in Serbia and Slovenia are presented in Tabs 2 and 3 (data for Serbia modified from Filipović et al. 2005; Group of authors 2001; for Slovenia from Frantar 2008). 
Tab. 3: Basic hydrological and geomorphological parameters for the Dinarides of Serbia and Slovenia.

\begin{tabular}{|c|c|c|}
\hline & Serbia & Slovenia \\
\hline $\begin{array}{l}\text { Catchments and } \\
\text { important rivers }\end{array}$ & $\begin{array}{c}\text { Black Sea: Drina, Sava, Zapadna Morava } \\
\text { Adriatic Sea: Beli Drim } \\
\text { Aegean sea: Lepenac }\end{array}$ & $\begin{array}{c}\text { Black Sea: Ljubljanica (in its karst basin), } \\
\text { Krka, Kolpa (72\%) } \\
\text { Adriatic Sea: Vipava, Reka (28\%) }\end{array}$ \\
\hline $\begin{array}{l}\text { Characteristic river } \\
\text { flows }\end{array}$ & $\begin{array}{l}\text { Sava }\left(Q_{\min }=285, Q_{a v}=1,532, Q_{\max }=6,408 \mathrm{~m}^{3} / \mathrm{s}\right) \\
\text { Drina }\left(Q_{\min }=55, Q_{a v}=371, Q_{\max }=5,831 \mathrm{~m}^{3} / \mathrm{s}\right) \\
\text { B. Drim }\left(Q_{\min }=1.5, Q_{a v}=24, Q_{\max }=959 \mathrm{~m}^{3} / \mathrm{s}\right)\end{array}$ & $\begin{array}{l}\text { Unica }\left(Q_{\min }=1, Q_{a v}=21, Q_{\max }=100 \mathrm{~m}^{3} / \mathrm{s}\right) \\
\operatorname{Krka}\left(Q_{\min }=3, Q_{a v}=52, Q_{\max }=356 \mathrm{~m}^{3} / \mathrm{s}\right) \\
\operatorname{Kolpa}\left(Q_{\min }=5, Q_{a v}=71, Q_{\max }=1,116 \mathrm{~m}^{3} / \mathrm{s}\right)\end{array}$ \\
\hline Altitude & 80 - 2,656 mASL & 0 - 1,797 mASL \\
\hline Highest peak & Djeravica (2,658 mASL) & Snežnik (1,796 mASL) \\
\hline
\end{tabular}

\section{GENERAL GEOLOGY AND HYDROGEOLOGY}

The Dinarides are a complex mountain chain, where morphological forms are sorted into longitudinal zones stretching parallel to the Adriatic Sea and the Panonnian Basin, representing a branch of southern tree of the Alps orogen. In a wider sense the Dinarides comprise the southern limestone Alps, the Dinarides in a narrow sense and the Serbian-Montenegrin part of the Hellenides. These three units, represented a unique geological whole which was divided into its parts by tectonic movements in the Neogene and Pleistocene, with to some extent altered and specific geologic characteristics (Pešić 2002). The border between the Dinarides and the Eastern Alps is Periadriatic fault, while the border with the Hellenides goes along Peć (Serbia)-Skadar (Albania) fault system striking. At the northern part the Dinarides in Serbia extends over the mountain of Fruška Gora (Group of authors 1976; Andjelković 1988; Filipović 2003; Filipović et al. 2005).

In geologic and tectonic view, the Dinaride space has been the matter of interest for numerous scientists for more than 100 years. In that period various, often contradictory theories concerning the origin, composition and tectonic structure of the Dinarides have been established (Cvijić 1924; Roglić 1965; Group of authors 1976; Herak 1977; Andjelković 1980; Mijatović 1984; Krešić 1987; Dimitrijević 1995; Milivojević et al. 1995; Dimitrijević 1996). As this is not the topic of our paper, only generally accepted principles of geologic composition and tectonic structure of the Dinarides having created conditions for the formation of significant groundwater reserves in karst aquifers of the Dinarides will be given further in the text.

The Dinaric karst developed in Mesozoic limestone. The youngest (Cretaceous, or even Tertiary) rocks form low relief along the coast and on the islands. In synclines, Eocene flysch was deposited and above there are isolated areas of erosional relief with short streams, thicker soil, and vegetation. Further inwards, the surface consists of Jurassic limestone, while in the east and northeast there are Triassic rocks, often dolomitic, but with less karst (Kranjc 2004).

For the Dinaric karst it is characteristic that the water drains to relatively small number of large karst springs. These have large catchments, which are often overlapping. Therefore it is very difficult to define their borders. As through the history of karstology the area of Dinaric karst has often been a study polygon, these characteristics are also relatively well known. Besides basic geological and hydrogeological investigations, a large number of tracer tests were carried out. In this way a lot of information about the direction and characteristics of groundwater flow, as well as about the extents of the recharge areas of karst springs was gathered. Very complex characteristics of groundwater flow were defined: flow from different ponors to a single springs, flow from one ponor to different springs, very high apparent flow velocities (in average around $125 \mathrm{~m} / \mathrm{h}$; Komatina 1984).

\section{DINARIC KARST IN SERBIA}

The complexes of rocks ranging from the Palaeozoic to Quaternary ages are singled out among lithographic units of the Western Serbia Dinarides. The Palaeozoic is most often represented by Carboniferous and Perm deposits. Schistose conglomerate, quartz, sandstone, limestone, argilloschist, clayey shale and phyllite form the Palaeozoic setting. These rocks constitute, first of all, waste terrains to the south of the Posava-Tamnava region as far as the Perućac-Užice line, as well as terrains to the east of Javor mountain and the mountain edge of the Metohija Basin. Lower Triassic werfenian flysch complex overlies the Palaeozoic complex. Regionally observed, these rocks are 
treated as the impermeable ones. Locally, a low capacity fissured aquifer formation is possible.

Triassic sediments are the most significant ones in the Dinarides region. The development of the Middle Triassic prevails, while the Lower and Upper Triassic is of significantly minor distribution. The mentioned werfenian flysch sediments occur in the setting of the Lower Triassic, being an ideal floor for the formation of a powerful karst aquifer formed in the Middle and Upper Triassic carbonate. The Middle Triassic is represented by bedding and thick-bedded limestone, dolomite, and dolomite limestone, limestone breccias. The thickness of Middle Triassic sediments ranges most often from 200 to 500 metres, 900 metres to the utmost (Milenić 2008). Upper Triassic sediments most often overlie Middle Triassic ones. They are represented by massive limestone, dolomites and limestone breccias, their thickness ranging from 10 to 300 metres (Milenić 2009). Karst aquifer is by its groundwater reserves and possibilities of its multi purpose usage the most significant one in the Dinarides region of Serbia. The carbonate deposits of Triassic age are largely distributed in the region of Western Serbia and can be followed along the whole belt of the Inner

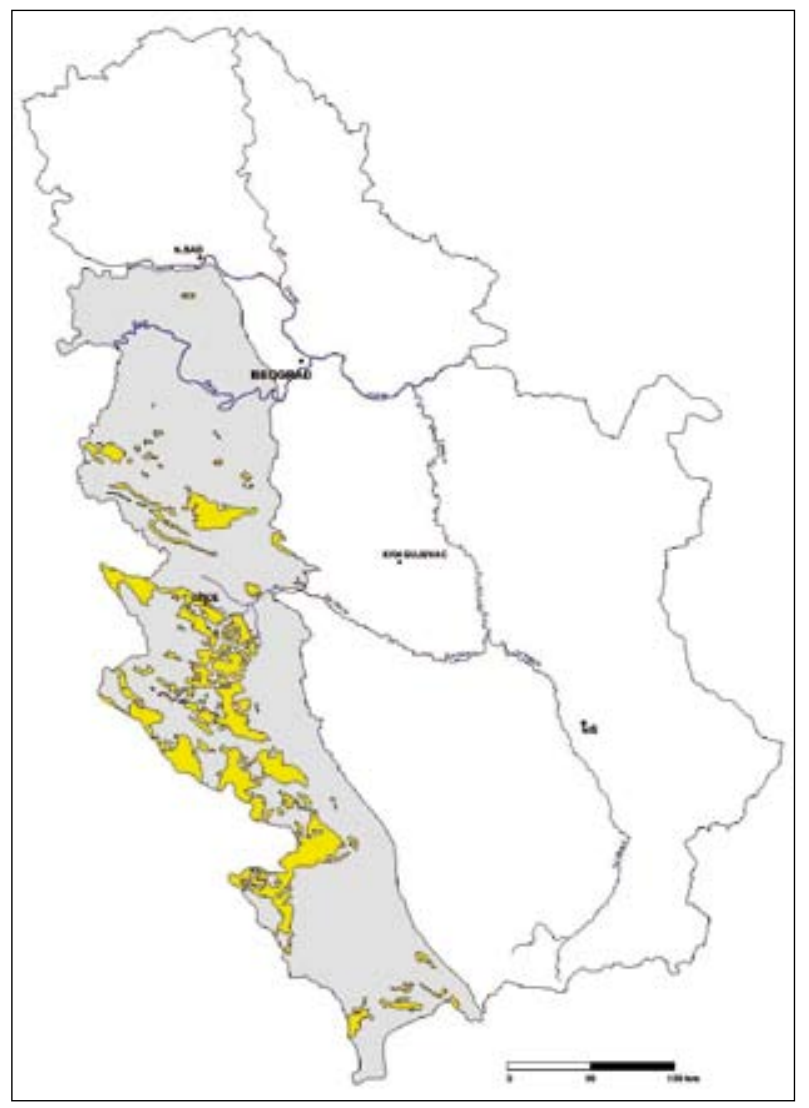

Fig. 3: Extent of the Dinaric karst in Serbia (in grey colour; outcrops of carbonate rock in yellow).
Tab. 4: Characteristic yields of some important springs in the Dinaric karst of Serbia (av.-average flow) and their locations within individual groundwater deposits.

\begin{tabular}{|l|c|c|}
\hline Spring & $\begin{array}{c}\text { Groundwater } \\
\text { deposit }\end{array}$ & Qmin./Qmax. \\
\cline { 3 - 3 } & Northern Metohija & $\mathrm{m}^{3} / \mathrm{s}$ \\
\hline Beli Drim & Northern Metohija & $1.5 / 14.7$ \\
\hline Istok & Tara-Zvijezda & $1.4 / 6.2$ \\
\hline Peručac & Sjenica basin & $1.0 />10$ \\
\hline Vapa & Pešter & $1.0 / 7.0$ \\
\hline Vrelo Bistrice & Sjenica basin & $1.0 / 1.5(\mathrm{av})$. \\
\hline Grabovica & Pešter & $2.0(\mathrm{av}) / 7.0$. \\
\hline Izvor Raške & Babine & $1.0 /-$ \\
\hline Seljašnica & Northern Metohija & $0.7 / 2.4$ \\
\hline Vrelo & Lelićki karst & $0.5 / 3.3$ \\
\hline Gradačka vrela & Podrimlje i Paštrik & $0.5 / 1.6$ \\
\hline Vrbničko vrelo & Jadovnik & $0.4 / 1.4$ \\
\hline Sopotnica & Pešter & $0.04 / 9.45$ \\
\hline Đerekarsko vrelo & Zlatibor & $0.46 /-$ \\
\hline Sušičko vrelo & Babine & $0.4 /-$ \\
\hline Bučje & Tara-Zvijezda & $0.15 /-$ \\
\hline Podstene-Rača & Lelićki karst & $0.1 />4.0$ \\
\hline Ključ-Mionica & Jadar-Kosjerić zone & $0.1 />2.0$ \\
\hline Orlovac & Lelićki karst & $0.1 />2.0$ \\
\hline Vrelo Paklje & & $0.1 / 1.0$ \\
\hline Petnica & & \\
\hline & & \\
\hline
\end{tabular}

Dinarides (Fig. 3). According to their characteristics two types of karst aquifer development can be distinguished: the first one within the Triassic zone where typical water table karst aquifers are in question with the recharging zone which overlaps with the surface of distribution, and the other one in the Jurassic ophiolitic zone with essentially different characteristics. On the basis of past investigations it is considered that the distribution of karst aquifer in the region of the Dinarides is larger than the distribution of Triassic carbonate on the surface of the terrain, which is shown by the way of discharging of numerous large springs, as well as the other characteristics of the karst aquifer regime. The Dinaric karst of Western Serbia is marked by more than 100 springs more powerful than 10 1/s (Mijatović 1997). Some of the most significant ones are given in Tab. 4.

Formations of Jurassic age are most often represented by formations of ophiolitic melange made of: marly limestone, sandstone, slate, hornstone, diabase, gabbro, serpentinite, periodotite, spilite, andesite, basalt. Their thickness ranges from 200 to 600 metres (Krešić 1987). 


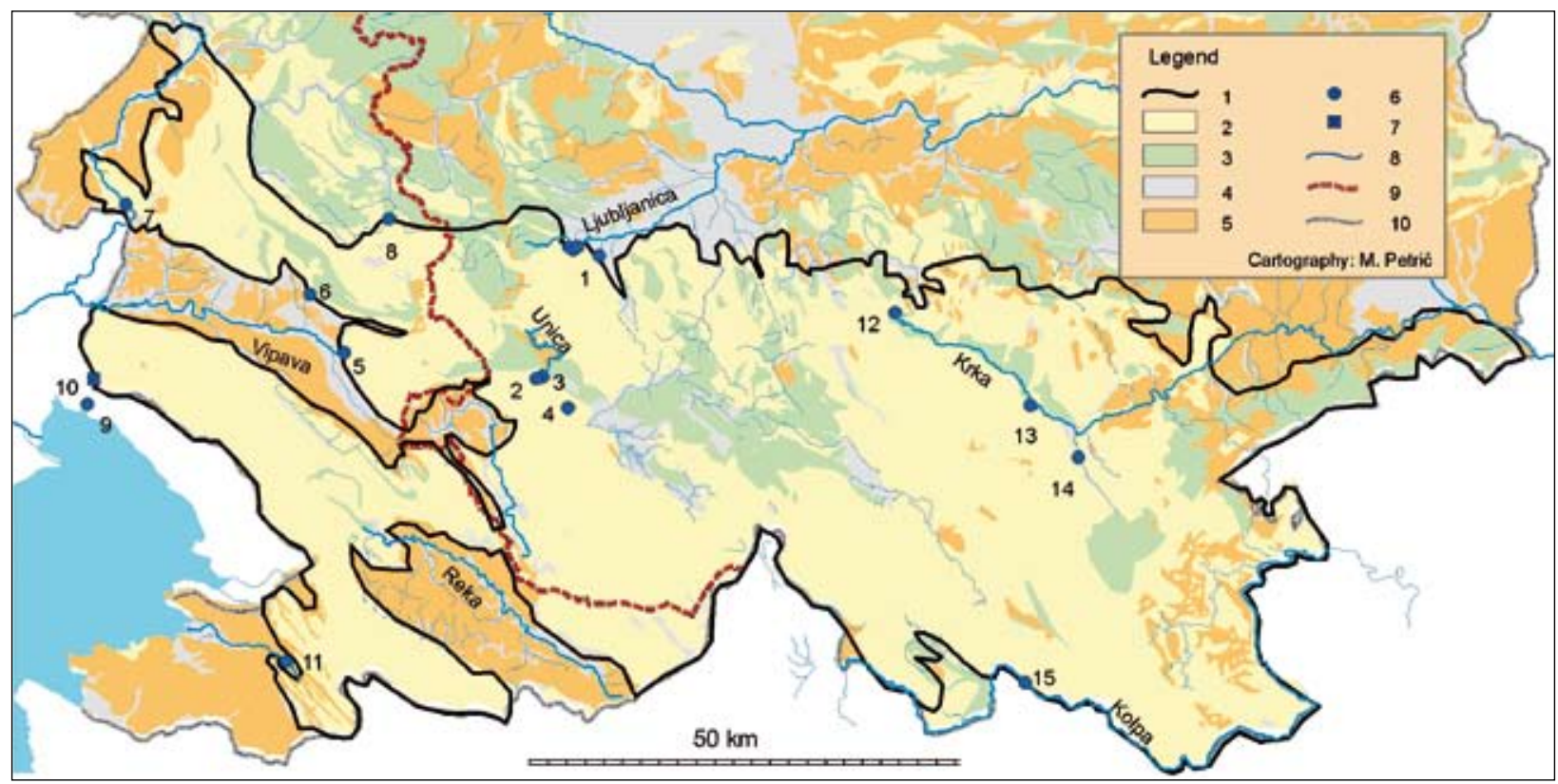

Fig. 4: Hydrogeological map of the Dinaric karst in Slovenia (Legend: 1. Boundary of the Dinaric karst, 2. Karst aquifer, 3. Fissured aquifer, 4. Porous aquifer, 5. Very poorly permeable rock, 6. Important karst spring (numbers refer to Tab. 5), 7. Pumping station, 8. Surface stream, 9. Adriatic-Black Sea watershed, 10. State border) (Source: Basic geological map 1:100,000, Geological Survey of Slovenia).

The development of fissured and karst-fissured aquifers is possible therein. Sediments of Cretaceous age have a significantly minor distribution in the region of the Dinarides than the rocks of Triassic and Jurassic ages. This era is mainly represented by conglomerate, breccia, sandstone, slate, limestone, dolomite and marl. There can occur in parts from the end of Cretaceous passing to Tertiary formations of volcanic origin.

Locally, older rocks are covered by Neogene sediments (artesian aquifers) and alluvial deposits (intergranular aquifers). The most significant Neogene basins are situated in the area of the Posavo-Tamnava and Metohija basin, while alluvial deposits reach the highest thickness along the valleys of the Sava, Drina, Kolubara, Zapadna Morava and Beli Drim, rivers.

In Dinarides of Western Serbia the total area of open karst structures is $2,960 \mathrm{~km}^{2}$, and of covered karst structures $535 \mathrm{~km}^{2}$. The total water reserves within them are approximately $6.5 \times 109 \mathrm{~m}^{3}$, the total minimal karst springflow $12.07 \mathrm{~m}^{3} / \mathrm{s}$, and the total average springflow or dynamic reserves $26.65 \mathrm{~m}^{3} / \mathrm{s}$. These data are taken from Stevanović (1995), where also a more detailed distribution in individual units of groundwater deposits is given.

\section{DINARIC KARST IN SLOVENIA}

In the paleogeographic sense the Dinarides in Slovenia comprise Southern Alps, and Internal and External Dinarides, but the term Dinaric karst refers only to the car- bonate rock of the latter. It extends over approximately $28 \%$ of the Slovene territory, in its southern part (Fig. 4). It is composed of limestone and locally dolomite of Mesozoic age. They mostly form well permeable aquifers with karst and fissured porosity. Some larger patches of dolomite act as slightly less permeable aquifers with fissured porosity. Very poorly permeable rock, mostly Eocene flysch, has an important hydrogeological role as an impermeable barrier along which karst groundwater emerges to the surface through numerous karst springs. On the other hand, surface waters from these non-karst areas sink at the contact with karst and represent important sources of the allogenic recharge of karst aquifers. Aquifers with intergranular porosity are developed in the slope rubble at the margins of high karst plateaux and in the alluvial sediments along surface streams.

The majority of karst-fissured aquifers are unconfined, with the exception of the confined deep (thermal) aquifers in the Dolenjska region in the eastern part.

The most important source of recharge is the autogenic infiltration of precipitation. Additionally, karst aquifers are recharged by sinking streams from nonkarst areas. For the area of the Dinaric karst relatively high specific runoffs from $10 \mathrm{l} / \mathrm{s} / \mathrm{km}^{2}$ in the south-western part up to $50 \mathrm{l} / \mathrm{s} / \mathrm{km}^{2}$ in the north-western part are characteristic, and the runoff coefficients range from 40 to 75 (Frantar 2008).

Karst springs are mainly located at the contact with very poorly permeable rock, which acts as an imperme- 
able barrier, or in the river valleys cut in the karst surface. The central part of the study area is the karst catchment of the Ljubljanica spring (No. 1 on Fig. 4). Its spring zone is composed of four main groups of springs with the common mean discharge of $39 \mathrm{~m}^{3} / \mathrm{s}$ (Gospodaric \& Habič 1976). For the catchment, interlacing between surface and underground flows in the system of successive karst poljes with inflow of water through big karst springs, such as Kotliči (No. 4 on Fig. 4), Malenščica (No. 3 ) and Unica (No. 2) springs, and outflow through the ponors at the other side of the polje are characteristic.

Tab. 5. Characteristic yields of some important springs in the Dinaric karst of Slovenia.

(Sources: Frantar 2008; Gospodarič \& Habič 1976; Kranjc 1997; Novak 1992).

\begin{tabular}{|c|c|c|}
\hline No. on Fig. 4 & Spring & $\begin{array}{c}\text { Qmin./Qmax. } \\
m^{3} / \mathrm{s}\end{array}$ \\
\hline 1 & Ljubljanica & $4.3 / 132$ \\
\hline 2 & Unica & $0.2 / 80$ \\
\hline 3 & Malenščica & $1.1 / 11.2$ \\
\hline 5 & Vipava & $0.7 / 70$ \\
\hline 6 & Hubelj & $0.2 / 59$ \\
\hline 7 & Mrzlek & $0.5 / 40$ (est.) \\
\hline 8 & Podroteja/Divje jezero & $0.2 / 40$ (est.) \\
\hline 9 & Timava & $9.1 / 127$ \\
\hline 11 & Rižana & $0.3 / 80$ \\
\hline 12 & Krka & $0.8 / 80$ \\
\hline 13 & Tominčev studenec & $0.5 / 10$ \\
\hline 14 & Radeščica & $0.35 / 40$ (est.) \\
\hline
\end{tabular}

For the area of Trnovo-Banjšice and Nanos high karst plateaux in the north-western part, groundwater flow with outflow through springs in the valleys at the foothills of the plateaux is characteristic. The most important among them are Mrzlek (No. 7), Hubelj (No. 6), Vipava (No. 5) and Podroteja/Divje jezero (No. 8) springs. All of them are captured for the water supply.

The area of Classical karst (named Kras) in the south-western part is drained toward the springs in the Trieste bay in Italy. The biggest among them is the Timava spring (No. 9). In the hinterland of the Slovene Littoral the most important is the Rižana spring (No. 11).

The Krka and Kolpa Rivers flow across the karst of the Dolenjska region in the eastern part. They are recharged by numerous karst springs, the biggest among them are the Krka spring (No. 12), Tominčev studenec (No. 13) and Radeščica spring (No. 14) in the Krka valley and the Bilpa spring (No. 15) in the Kolpa valley.

\section{CASE STUDY 1: THE USE OF TRACER TESTS IN HYDROGEOLOGICAL RESEARCHES}

In the previous chapter some general hydrogeological characteristics of the Dinaric karst in Serbia and Slovenia were compared. For a better understanding of the functioning of karst aquifers a more detailed survey is necessary. Similar research methods are used in the two countries (Fig. 1). One of the most efficient research methods in karst hydrogeology are tracer test, which were proved a valuable research tool in many investigations carried out in the area of Dinaric karst. To emphasise their importance, as well as to give some recommendations for their efficient use, some results of their application on the Dinaric karst in Slovenia are presented below.

Based on the review of published and unpublished results of more than 220 tracer tests with artificial tracers, carried out on the Slovene karst during the period from 1907 to 2008, a data base was created at the Karst Research Institute. The area of Dinaric karst covers approximately $66 \%$ of Slovene karst, yet $78 \%$ of registered tracer tests was performed there (Fig. 5).

In the majority of tests the sinking streams were selected as the injection points. However, in recent years for more detailed studies of the characteristics of the vadose zone the injection at the karstified surface without a concentrated surface flow has been often implemented. In the area of Dinaric karst several such tests were performed at the Trnovo-Banjšice plateau (Kranjc 1997; Bricelj \& Čenčur Curk 2005) and in the applied studies of the influence of various sources of pollution on karst waters (Kogovšek \& Petrič 2004, 2006, 2007; Kogovšek et al. 2008).

In $71 \%$ of performed tracer tests the fluorescent dye uranine was used, and in an additional 13\% other fluorescent dyes. They remain the most popular tracers, even though new substances were introduced in recent years. However, with the improvement of the methodology, the capacity and accuracy of detection increased, therefore the amount of tracer needed to be injected is now adequately lower.

Reviewed reports indicate that the quality of the results depends highly on the quality of previous research and an adequate preparation of the test. The tracer tests can be successful and the results obtained of sufficient quality only when they are planned based on previously collected hydrogeological data. Furthermore, a long-term sampling should be performed, because even though the velocity of groundwater flow in karst aquifers is high, they also have a capacity of longer storage within the low-permeability parts of the vadose zone (Kogovšek \& Petrič 2004). When the duration of sampling is too short, some important information about the studied system can be overlooked. 


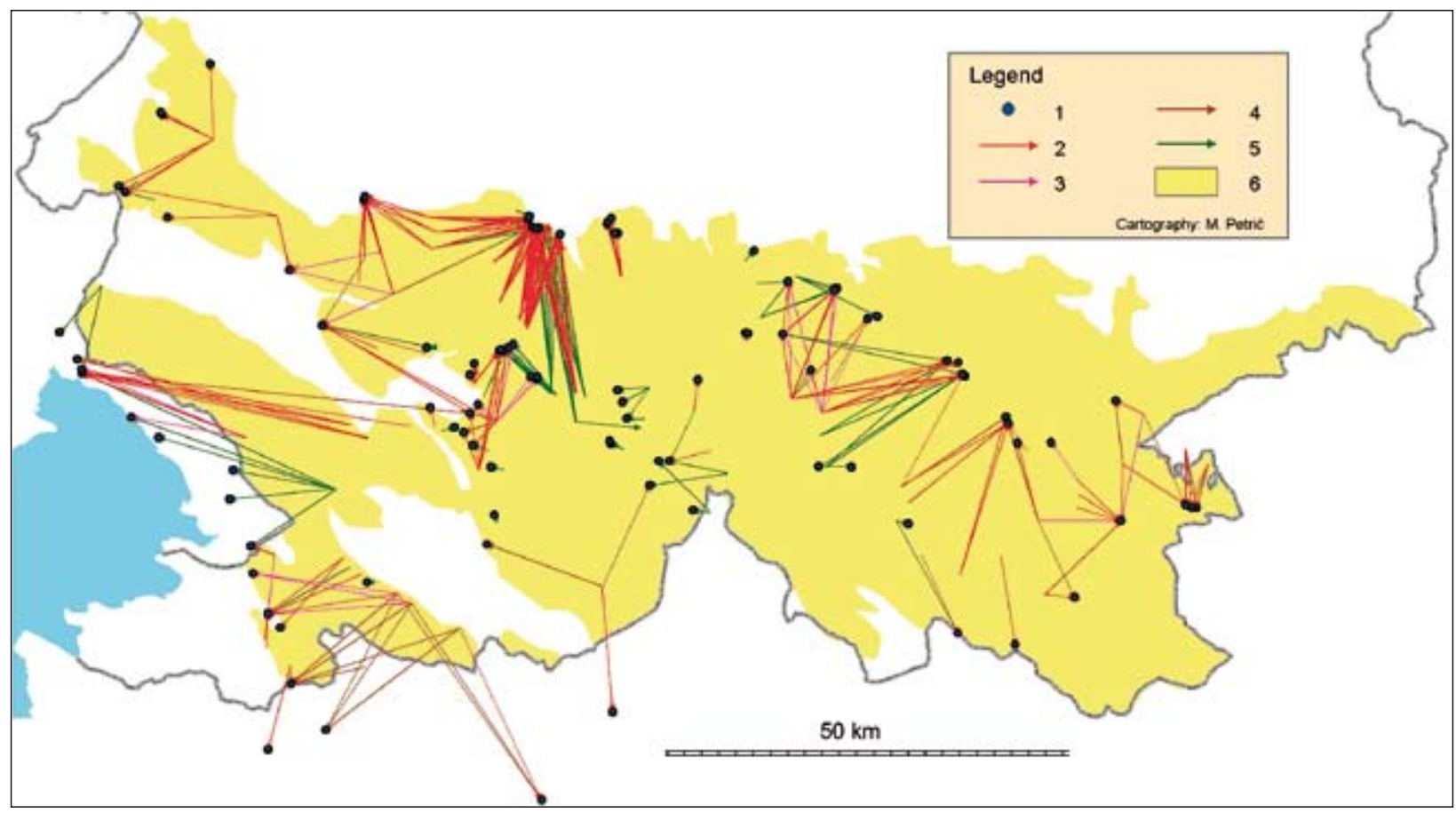

Fig. 5: Results of tracer tests, carried out in the area of Dinaric karst in Slovenia (Legend: 1. Spring, 2. Main underground water connection, 3. Secondary underground water connection, 4. Uncertain underground water connection, 5. Underground water connection, proved by tracer test before 1974, 6. Karst area).

Results of tracer tests with artificial tracers are an important tool for the planning of various interventions on karst and above all for the efficient planning of the monitoring of possible negative influences of pollution on karst waters. They help us to understand a complex functioning of karst systems that is also reflected in their transboundary character (Fig. 5).

In recent years, also tracing with environmental tracers is becoming more and more important. The most important group of these naturally occurring tracers are the natural physical and chemical characteristics of water (Kogovšek 2001, 2004; Bonacci \& Andrić 2008), as well as its isotope content (Trček 2007; Doctor 2008). A continuous monitoring of discharges, and physical and chemical parameters, as well as the comparison of these parameters with the characteristics of precipitation and sinking streams in the recharge areas, enable the inference about the dynamics of groundwater flow and transport of substances. As an example, the data for the adjacent Unica and Malenščica springs and the sinking Pivka stream in their catchment during a selected water wave are shown in Figure 6. Rapid reaction of the measured parameters to precipitation events indicates a well developed karst aquifer with quick flow through the main drainage paths. The changes are more intensive in the Unica spring due to the important influence of the sinking Pivka stream, which has the most intensive reactions to the changes of hydrological conditions. They result in the changes of specific electrical conductivity in the Unica spring with a certain time lag, as well as with smaller intensity due to some additional inflows from other parts of the recharge area of this spring. Significantly more

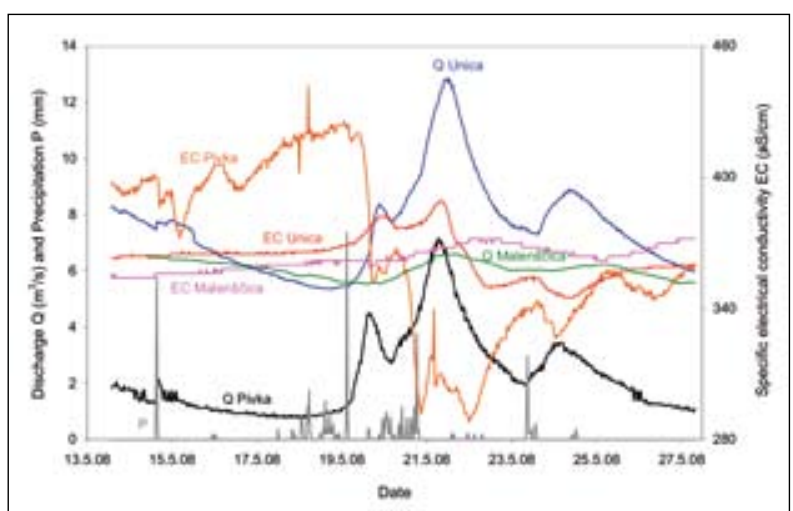

Fig. 6: Important information about the functioning of karst aquifers can be obtained by the comparison of the characteristics of precipitation, sinking stream and springs.

stable are recorded parameters of the Malenščica spring, which indicate different characteristics of the groundwater flow toward this spring. Similar comparisons could be done for other described springs. 


\section{CURRENT STATUS OF GROUNDWATER RESOURCES AND THEIR USAGE}

\section{WATER SUPPLY}

In the counties of Western Serbia Dinarides karst groundwater is used as shown (Stevanović et al. 1997):

- Kolubara county: $0.233 \mathrm{~m}^{3} / \mathrm{s}$ (70\% karst groundwaters),

- Zlatibor county: $0.675 \mathrm{~m}^{3} / \mathrm{s}$ (50\% karst groundwaters),

- Raška county: $1.052 \mathrm{~m}^{3} / \mathrm{s}$ (60\% karst groundwaters),

- Peć county: $0.380 \mathrm{~m}^{3} / \mathrm{s}$ (>90\% karst groundwaters),

- Prizren county: $0.397 \mathrm{~m}^{3} / \mathrm{s}$ (>90\% karst groundwaters).

Four water bodies, defined in the area of Dinaric karst in Slovenia, have important quantities of available groundwater (Andjelov et al. 2006):

- Karst Ljubljanica in the central part $\left(2.9 \mathrm{~m}^{3} / \mathrm{s} ; 7.5 \%\right.$ used for water supply),

- Littoral and Kras with Brkini in the south-western part $\left(1.2 \mathrm{~m}^{3} / \mathrm{s} ; 26.0 \%\right.$ used),

- Goriška Brda and Trnovo-Banjšice plateau in the north-western part $\left(3.9 \mathrm{~m}^{3} / \mathrm{s} ; 10.9 \%\right.$ used),

- Dolenjska karst in the eastern part $\left(6.3 \mathrm{~m}^{3} / \mathrm{s} ; 5.6 \%\right.$ used).

Among almost 500 registered sources of water supply in this area, $78 \%$ are springs, and the rest are wells. Often boreholes were drilled near the springs to increase their capacity. The only larger area supplied exclusively from the wells is the Kras area $(21,000$ inhabitants in 5 municipalities) with the pumping station at Klariči (No. 10 on Fig. 4).

\section{GROUNDWATER BOTTLING}

The industry of ordinary low mineralised and mineral carbon-acid water bottling is expanding in Serbia. Among over 20 brands, present in Serbia, six water bottling factories with overall filling capacity of over 50 million units annually, are working on the territory of Dinaric karst currently. All six occurrences are related to Dinaric karst being: Voda Jazak from the Fruška Gora GW deposit, Manastir Tronoša from the Jadar-Kosjerić GW deposit, Vujić voda and Voda Voda from the Lelićki karst GW deposit, and Zlatibor voda and Kraljeva voda from the Zlatibor GW deposit.

In the area of Dinaric karst in Slovenia, the water named Costella is pumped from the borehole drilled in Upper Triassic dolomite in the Kolpa valley.

\section{THERMOMINERAL WATER}

Over 270 mineral, thermal, and thermomineral occurrences are registered on the territory of Serbia nowa- days (Filipović 2003; Krunić 1999). About fifty belong to Dinaric karst, which represents about $20 \%$ of overall number.

Thermomineral water occurs in the form of spring and well and flow out from unconfined, semi confined, and confined karst structure. The highest registered temperature is $80^{\circ} \mathrm{C}$ (Bogatić) and it is connected to the hydrothermal system of Mačva. However, the largest number of them has the temperature of $35^{\circ} \mathrm{C}$. The chemical composition is varied, the mineralization is mainly to $1 \mathrm{~g} / \mathrm{l}$, and water is of $\mathrm{HCO}_{3}-\mathrm{Ca}, \mathrm{Mg}$ type. From the balneologic aspect various medical treatments are possible. Some of these spas have been famous for ages. The most interesting thermomineral occurrences in karst aquifers are:

- Pribojska Banja spa (spring, $\mathrm{T}=36^{\circ} \mathrm{C}, \mathrm{Q}=80 \mathrm{l} / \mathrm{s}$ ),

- Banja Vrujci spa (wells, $\mathrm{T}=26^{\circ} \mathrm{C}, \mathrm{Q}>50 \mathrm{l} / \mathrm{s}$ ),

- Ovčar banja spa (wells, $\mathrm{T}=38^{\circ} \mathrm{C}, \mathrm{Q}>30 \mathrm{l} / \mathrm{s}$ ),

- Bogatić (well, $\mathrm{T}=80^{\circ} \mathrm{C}, \mathrm{Q}>50 \mathrm{l} / \mathrm{s}$ ),

- Visoka (springs, $\mathrm{T}=25^{\circ} \mathrm{C}, \mathrm{Q}>50 \mathrm{l} / \mathrm{s}$ ).

In Slovenia 51 geothermal locations with the temperature of water on the surface above $20^{\circ} \mathrm{C}$ are known; at 18 of them water is thermomineral. In the area of Dinaric karst there are 11 geothermal locations (3 with thermomineral water), mostly in Triassic and Jurassic dolomite and limestone. In general, waters belong to the $\mathrm{Ca}-\mathrm{Mg}-\mathrm{HCO}_{3}$ type with temperatures between $20^{\circ} \mathrm{C}$ and $64^{\circ} \mathrm{C}$ (Lapajne 2006). Thermal and thermomineral waters are used mainly for the balneologic purposes (spas), and partly for the heating of greenhouses.

\section{HYDROGEOTHERMAL ENERGY}

According to the current level of the knowledge of geological composition and hydrogeothermal characteristics of the terrain to depth of $3,000 \mathrm{~m}$, there are 60 convective hydrothermal systems on the territory of Serbia (Milivojević et al. 1995). Out of that number, 30 are situated in Dinaric karst of Western Serbia. Hydrothermal energy is used in more than 10 locations on the territory of Western Serbia Dinarides for interior residential heating, recreation, and balneology, in green houses, cloches, for breeding of fish, pigs, and poultry, for drying of agricultural products, as well as, for industrial purposes.

In addition to high temperature geothermal occurrences, the usage of low temperature water with the temperature to $20^{\circ} \mathrm{C}$, whose energy is utilised with the help of heat pumps, is increasing. 


\section{GROUNDWATER PROTECTION}

The aquifers of the Dinaric karst are very vulnerable to various human activities. The time for a reaction after a possible pollution event is very short, because the transport of pollution from the source to the karst spring is very rapid. Therefore it is very important to follow the prescribed protection measures within the protection zones.

In Slovenia the basic law which regulates the management of water resources, is the Waters Act (2002). The protection of waters against pollution is regulated by the Environment Protection Act (2004), and the supporting decrees. The basic legislative rule for the protection of individual water sources are decrees, which were in the past accepted at the level of municipalities, while according to the new Waters Act this becomes a responsibility of the state. First the expert basis should be prepared in accordance with the Regulations of criteria for planning and determination of protection zones of drinking water resources (2004), in which specific criteria for karst aquifers are set. Three protection zones are defined: the inner, middle and outer zone. The areas with assessed travel times of pollution toward the source less than 12 hours belong to the inner zone, and the areas with travel times more than 12 hours to the middle zone. The outer protection zone comprises the entire recharge area of the source. To assess the travel times, the use of one or more research methods is foreseen, but not precisely defined, which opens the possibility for less accurate delineation of protection zones. These problems are discussed in more details by Ravbar and Kovačič (2006), and Ravbar and Goldscheider (2007).

Unfortunately, the new legislation has been implemented on a minority of the waters sources. For the majority, the decrees for protection were defined according to the old legislation at the level of municipalities. Various methodologies were applied for the delineation of the protection zones. Usually four zones are defined: $1^{\text {st }}$-catastrophic, $2^{\text {nd }}$-high, $3^{\text {rd }}$-medium, $4^{\text {th }}$-low. Altogether almost one third of the Dinaric karst lies within the protection zones (Fig. 7). For this assessment the data published by the Environmental Agency on their web page was elaborated (Eurowaternet Slovenija 2008). At the state level protected areas cover $385 \mathrm{~km}^{2}$ (2.8\% in inner, $31.2 \%$ in middle, and $66 \%$ in outer zone), and at the level of municipalities $1,524 \mathrm{~km}^{2}\left(0.5 \%\right.$ in $1^{\text {st }}, 12.6 \%$ in $2^{\text {nd }}, 40.9 \%$ in $3^{\text {rd }}$, and $46 \%$ in $4^{\text {th }}$ zone). Such a large extent of the protection zones lead to serious difficulties in the planning of the development of these areas, and is probably one of the reasons why the implementation of the protection measures in praxis often does not follow the legislation.

The concept of groundwater protection in Serbia is regulated by the basic Regulations on determining and maintaining of sanitary protection zones of water sup-

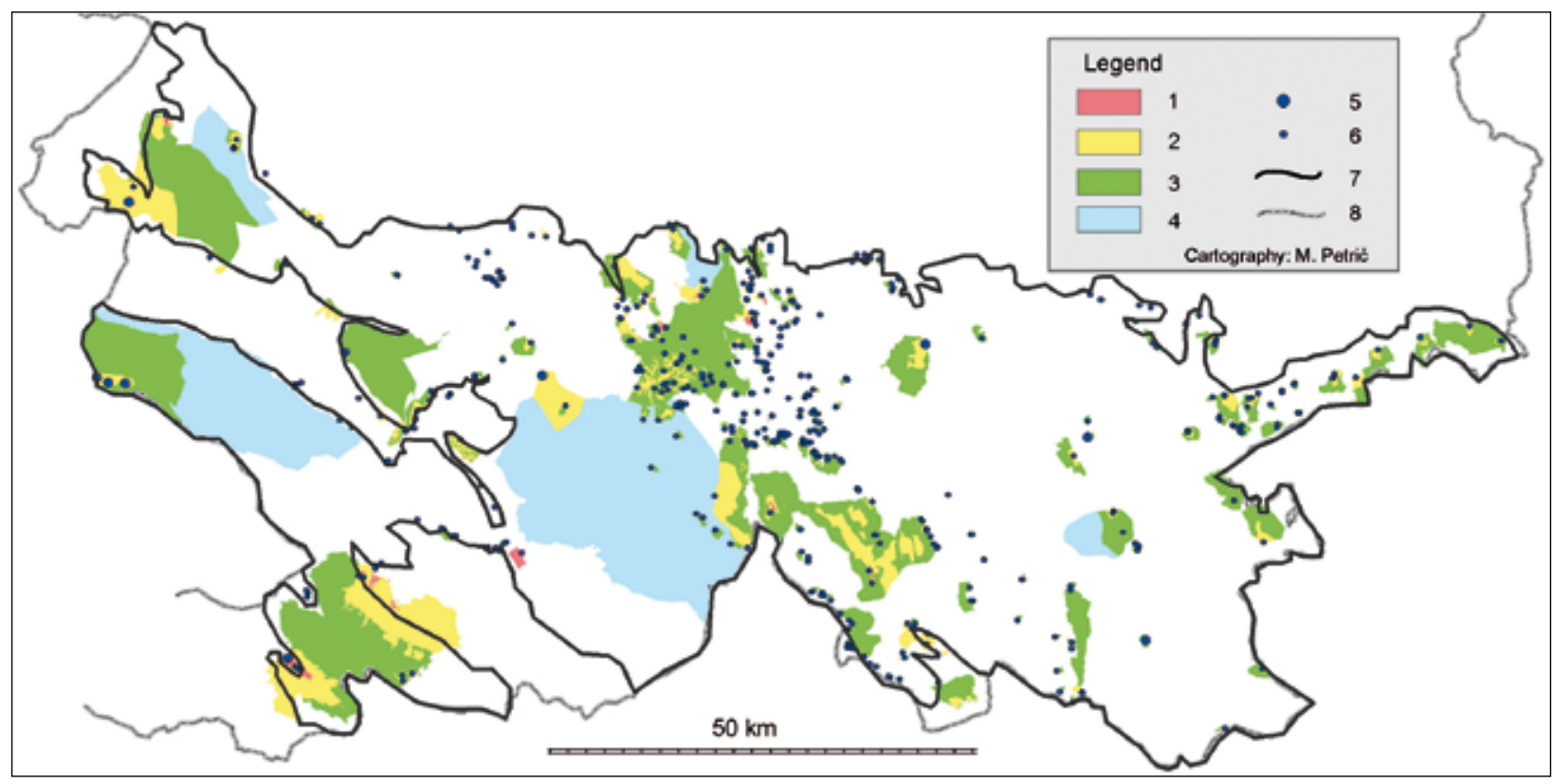

Fig. 7: Protected water sources and the protection zones (Legend: 1. $1^{\text {st }}$ protection zone, 2. $2^{\text {nd }}$ protection zone, 3. $3^{\text {rd }}$ protection zone, 4. $4^{\text {th }}$ protection zone, 5. Protected more important water source, 6. Protected water source, 7. Boundary of the Dinaric karst, 8. State border; Source: Eurowaternet Slovenija 2008). 
ply sources (2008). Additionally, there are in effect provisions of Law on Geologic Investigations (1995), Law on Waters (1991), Law on Environmental Protection (2004) and other documents regulating the way of investigation, exploitation and groundwater protection.

The especially complex process is to single out sanitary protection zones in karst and karst fissure aquifers. Owing to specific distribution conditions of karst aquifer (watershed border changes and the aberration of topographic and hydrogeologic water divide), the intensity of karstification process, the water flow velocity, the knowledge of a large number of parameters is required to determine the mentioned zones precisely (Fig. 8).

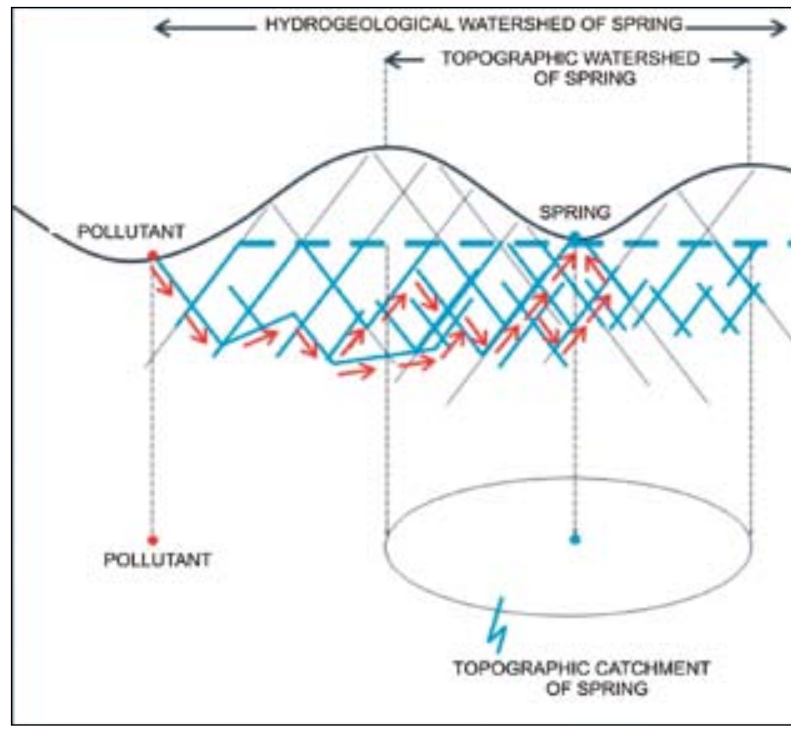

Fig. 8: Example of complexity in karst and karst-fissured aquifers protection owing to disparity of hydrogeologic and topographic large spring watershed (Krešić et al. 2006).

\section{CASE STUDY 2: ENVIRONMENTAL IMPACT OF SAWMILL BY-PRODUCTS DEGRADATION}

Various sources of pollution endanger groundwater quality in the area of Dinaric karst. In the two countries compared, the wood and timber industry is one of such characteristic sources, therefore a case study of karst groundwater pollution from Western Serbia is presented below. Applied industrial procedures leave behind significant by-products, regularly harmful and with negative impact on the quality of the environment.

The areas especially rich in forests and timber are situated in Dinaric karst in Western Serbia. In the municipality of Nova Varos, the Zlatar Mountain is a big karst natural resource as to forest and water resources. The forest resource is highly utilised, which can be confirmed by a large number of newly opened saw mills and lumber mills. However, although with a positive trend in economic sense, a large number of saw mills is not registered and works in so called "grey" area. Thus there are neither records nor adequate environmental protection measures, as to correct managing of the forest waste after processing.

The mechanisms of groundwater pollution by wood and timber industry waste (first of all by sawdust) is highly complex and requires a multidisciplinary approach. It is known that fresh sawdust impact to the quality of environment directly occurs with time by decaying, wearing and degradation of incorrectly disposed sawdust. After certain time, sawdust, in contact with the soil and in anaerobic conditions, can result in forming of high content of phenol, methane, iron, manganese, and other elements. When geological-hydrogeological conditions are favourable, the contact with groundwaters occurs, and their direct contamination takes place.

The chemical composition of sawdust depends on the kind of wood, soil conditions and external factors. Except inorganic compounds, numerous organic compounds of highly complex structures make the composition of sawdust. The elementary analysis of sawdust has shown that the proportion of carbon is the highest with $50 \%$, and then there comes oxygen with $40 \%$, hydrogen with about $6 \%$ and nitrogen with about $1 \%$. Among organic compounds the proportion of cellulose is the highest, about $40 \%$, lignin about $28 \%$ and chemical cellulose of about $27 \%$.

Sawdust, as the most common waste, endangers water potential of Zlatar Mountain directly. Groundwaters are formed in karst aquifer primarily in limestones of Triassic and Jurassic ages. Practically, whole Zlatar holds qualitative groundwaters, which are currently being used for the water supply of the Nova Varos municipality. The most significant springs of the north edge of Zlatar from the point of view of both quantity and quality are: Lakomica, Gačevo vrelo, Bjelanac, etc.

During the year 2003, a serious chemical pollution with iron and manganese was recorded at the Bjelanac spring. This pollution resulted in the degradation of water quality on this spring, thus the waters from it have been used only for technical purposes since that time. Before the Bjelanac spring was used for the water supply of the Akmacici settlement with more than 2,000 inhabitants. Also, in the last three years strong muddiness appeared occasionally out of deposition of materials identical to the appearance of dissolved sawdust.

Although, in the beginning it was doubted that the source of pollution was a dairy nearby, on the basis of carried out investigations, it was found out that the main source of pollution was, in fact, inadequately deposited sawdust in the broad neighbourhood. 


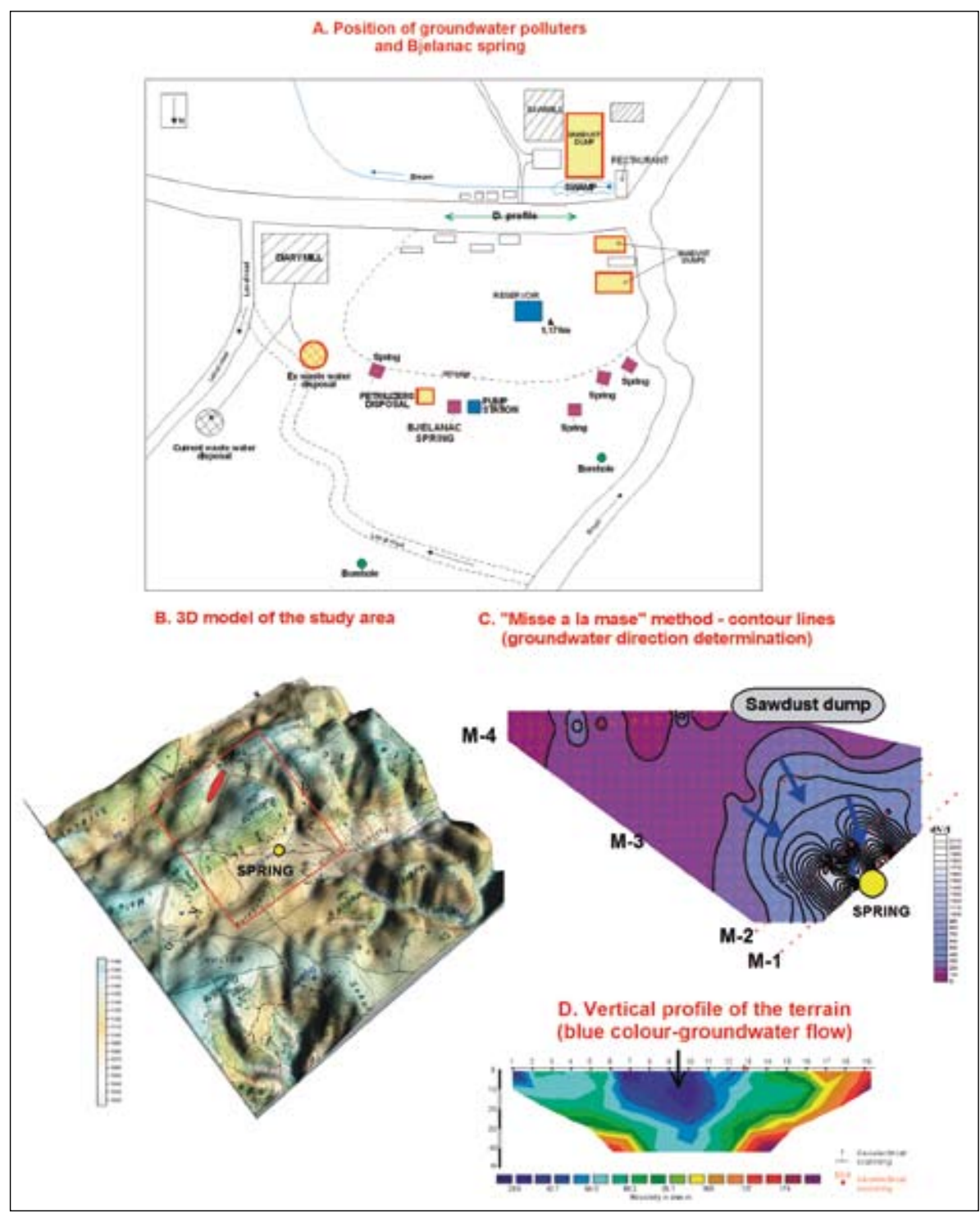

Fig. 9: Case study 2 - graphical explanation.

Hydrogeological investigations were carried-out through a number of phases (Milenić et al. 2007). They can be represented shortly as:

- A collecting, a selection, an analysis, and the reinterpretation of all existing geographic, climatic, hydrographic, hydrologic, geologic, hydrochemic, and hydrogeological data about the survey field i.e. the area of the recharge zone of the Bjelanac spring - problem defining.

- The making of 3D elevation and geological-hydrogeological model of the broad neighbourhood of the spring, on the basis of which, possible physical models of groundwater movement in the zones of potential pollutants have been determined - defining of the exploration directions.

- Hydrogeological reconnaissance and hydrogeological mapping, namely detailed recording of all hydrogeological phenomena and buildings on the survey field and sampling for chemical analyses - realization of the First phase of the field exploration.

- Geophysical exploration. In this phase, geoelectrical sounding, geoelectrical mapping (scanning) as well as, the application of the „mise a la masse“ method were conducted. The mentioned investigations were carried out because of the space delineation, namely the delineation of water bearing horizon, as well as, direct determination of the direction of groundwater movement through the karst aquifer in the area of north edge of Zlatar Mountain - realization of the Second phase of the exploration.

- Chemical analyses of samples of groundwaters and soil. tion.

- Analysis of obtained results and their interpretaaquifer.

- Proposal of remediation measures for polluted

- Proposal of protection measures of "clear" groundwaters. 


\section{DISCUSSION AND PERSPECTIVES}

In the Serbian part of the study area the actually exploitable part of the water potential is $14.6 \mathrm{~m}^{3} / \mathrm{s}$. In the Slovene part the total available amount of water is $14.3 \mathrm{~m}^{3} / \mathrm{s}$, but at the moment only approximately $9.1 \%$ of this amount is used for the water supply (Andjelov et al. 2006). With the intention of emphasising the importance of these resources we quote that the total amount of water used in Serbia for the public water supply in 1994 was $20.6 \mathrm{~m}^{3} / \mathrm{s}$ (Belgrade and Vojvodina not included) (Dokmanović 1997), and in Slovenia in 2004 approximately $5.1 \mathrm{~m}^{3} / \mathrm{s}$ (SURS 2009). In the last decade a new sphere of activity was opened by the growth of the use of bottled water. Many of the bottling plants take water from the area of Dinaric karst, and according to the potential of its reserves their number will surely increase in the future.

Due to these important reserves of quality water, many hydrogeological researches were carried out in the past in the area of Dinaric karst in the two countries, and because of their high potential the studies will be even more detailed in the future. The review of applied methodology (Fig. 1) can be used as a valuable help for planning efficient hydrogeological investigations there as well as in karst areas elsewhere. Two characteristic case studies are described in more detail. A long tradition of the use of tracer tests in the Slovene part of the study area is a good basis for the further development and improvement of the method. The importance of adequate previous hydrogeological researches and thorough preparation of the test is emphasised. A long dura- tion of sampling and an accurate detection of the tracers are necessary for the success of the tests. The second case study deals with a concrete example of a pollution accident with a significant deterioration of the water quality in the spring within the Dinaric karst of Serbia. A detailed and well planned hydrogeological research proved to be an efficient tool for the detection of the pollution source, as well as for the planning of operative remedial measures, and can be used as an example of good practice for solving similar problems in other karst areas.

Considering various environmental stresses, including climate changes, it is necessary to implement the monitoring of water resources in order to assess possible influences to their regime and reserves. Additionally, the protection measures should be revised, and adapted to the European guidelines and specific characteristics of karst aquifers. In Serbia a register of pollution sources is missing and a proper data base is not available, therefore it is a priority task to set up such inventory in the near future.

Due to a specific geographical position, many of the described karst aquifers extend across the administrative borders to the neighbouring countries. Their transboundary character was proved by the tracer tests also. In the article the study areas in Slovenia and Serbia were compared, but to improve the management of water resources in the Dinaric karst it would be very important to co-operate also with other countries in this area in the common projects on shared aquifers

\section{CONCLUSIONS}

Investigation, exploitation, regulation and control of water resources in karst, has become the leading discipline of applied hydrogeology recently. The presented investigations are result of the work of the paper authors within the two year bilateral project on the determination of current status and defining of perspectives in the usage of groundwater of the Dinaric karst of Serbia and Slovenia.

Through comparative approach, all karst deposits in the mentioned regions, as well as, the status regarding the usage, protection and development perspectives were identified quantitatively.
The presented values of karst groundwater in the Dinarides of Serbia and Slovenia represent only signs of enormous potential this space owns. This paper, among other things has had the aim to determine advantages and disadvantages of groundwater resource management in both states through bilateral approach. Therefore, its rapid and inevitable development is necessary respecting the principle of sustainable development as a gift to coming generations. 


\section{ACKNOWLEDGEMENTS}

This paper was conducted within the Project of basic investigations of the Ministry of Science and Technological Development of the Republic of Serbia - Investigation, evaluation and significance of groundwater resources in concept of sustainable development (ON146018), research programme Karst Research at the Slovenian Research Agency, and the agreement on scientific and business technical cooperation between SRC SASA, University of Nova Gorica, and Faculty of Mining and Geology - University of Belgrade.

\section{REFERENCES}

Andjelković, M., 1980: Tectonics of the Inner and Central Dinarides.- Faculty of Mining and Geology, pp. 204, Belgrade.

Andjelković, M., 1988: Geologija Jugoslavije.- Građevinska knjiga, pp. 692, Belgrade.

Andjelov, M., Gale, U., Kukar, N., Trišič, N. \& J. Uhan, 2006: Ocena količinskega stanja podzemnih voda $\mathrm{v}$ Sloveniji.- Geologija, 49, 2, 383-392.

Bonacci, O. \& I. Andrić, 2008: Sinking karst rivers hydrology: Case of the Lika and Gacka (Croatia).Acta carsologica, 37, 2-3, 185-196.

Bricelj, M. \& B. Čenčur Curk, 2005: Bacteriophage transport in the unsaturated zone of karstified limestone aquifers.- In: Stevanović, Z. \& P. T. Milanović (eds.) Water resources and environmental problems in karst, Proceedings of the International conference and field seminars, 13-19 September 2005, Belgrade, Kotor. Institute of Hydrogeology, Faculty of Mining and Geology, 109-114, Belgrade.

Cvijić, J., 1924: Geomorfology I.- National Printing House, pp. 588, Belgrade.

Dimitrijević, M. D., 1995: Geologija Jugoslavije.- Geoinstitute, pp. 205, Belgrade.

Dimitrijević, M. D., 1996: Geology of the Zlatibor Mountain.- Special publication 18, Geoinstitute, pp. 176, Belgrade.

Doctor, D. H., 2008: Hydrologic connections and dynamics of water movement in the classical Karst (Kras) aquifer: Evidence from frequement chemical and stable isotope sampling.- Acta carsologica, 37, 1, 101-123.

Dokmanović, P., 1997: Possibilities of water supply by groundwater of tertiary basins in Serbia.- In: Proceeding of the Conference: 100 years of Hydrogeology in Serbia. Faculty of Mining \& Geology, 113-119, Belgrade.

Environment Protection Act, 2004: Official Gazette of the Republic Slovenia, 41/2004, 4818-4853.

Eurowaternet Slovenija, 2008: Protected Water Resource Areas.- [Online] Available from: http://eionet-
si.arso.gov.si/Dokumenti/GIS/voda/ [Accessed $5^{\text {th }}$ April 2008].

Filipović, B., 2003: Mineral, thermal and thermomineral waters of Serbia.- Serbian spas and resort Association \& Faculty of Mining and Geology, pp. 279, Belgrade.

Filipović, B., Krunić, O. \& M. Lazić, 2005: Regional hydrogeology of Serbia.- Faculty of Mining \& Geology, pp. 401, Belgrade.

Frantar, P. (ed.), 2008: Water Balance of Slovenia 19712000.- Ministry for Environment and Spatial Planning-Environmental Agency of the Republic of Slovenia, pp. 120, Ljubljana.

Gospodarič, R. \& P. Habič (eds.), 1976: Underground water tracing. Investigations in Slovenia 1972-1975.Institute Karst Research, pp. 312, Ljubljana.

Group of authors, 1976: Geology of Serbia-Hydrogeology.Faculty of Mining \& Geology, pp. 248, Belgrade.

Group of authors, 2001: Republic of Serbia water resources master plan.- Institute for the development of water resources „Jaroslav Cerni“, pp. 369, Belgrade.

Herak, M., 1977: Tecto-genetic approach to the classification of karst terrains.- Krš Jugoslavije, 9, 4, 227 238.

Kogovšek, J., 2001: Monitoring of the Malenščica water pulse by several parameters in November 1997.Acta carsologica, 30, 1, 39-53.

Kogovšek, J., 2004: Physico-chemical properties of waters in the Malenšcica recharge area (Slovenia).Acta carsologica, 33, 1, 143-158.

Kogovšek, J. \& M. Petrič, 2004: Advantages of longerterm tracing -- three case studies from Slovenia.Environmental geology, 47, 76-83.

Kogovšek, J. \& M. Petrič, 2006: Tracer test on the Mala gora landfill near Ribnica in south-eastern Slovenia.- Acta carsologica, 35, 2, 91-101.

Kogovšek, J. \& M. Petrič, 2007: Directions and dynamics of flow and transport of contaminants from the landfill near Sežana.- Acta carsologica, 36, 3, 413424. 
Kogovšek, J., Prelovšek, M. \& M. Petrič, 2008: Underground water flow between Bloke plateau and Cerknica polje and hydrologic function of Križna jama, Slovenia.- Acta carsologica, 37, 2-3, 213-225.

Komatina, M., 1984: Hydrogeologic features of the Dinaric karst.- In: Mijatović, B. F. (ed.): Hydrogeology of the Dinaric Karst. International contributions to Hydrogeology, 4, pp. 55-73, Heise Verlag, Hannover.

Kranjc, A. (ed.), 1997: Karst Hydrogeological Investigations in South-Western Slovenia.- Acta carsologica, 26, 1, pp. 388, Ljubljana.

Kranjc, A., 2004: Dinaric Karst.- In: Gunn, J. (ed.): Encyclopedia of Caves and Karst Science. Fitzroy Dearborn, pp. 287-289, New York, London.

Krešić, N., 1987: Karstic hydrogeological systems in ophiolites belt of Inner Dinarides of Serbia.- PhD thesis. Faculty of Mining \& Geology, Belgrade, pp. 210.

Krešić, N., Vujasinović, S. \& I. Matić, 2006: Remediation of groundwater and geoenvironment.- Faculty of Mining \& Geology, Dept. of Hydrogeology, Belgrade, pp. 385.

Krunić, O., 1999: Thermomineral waters in Serbia - basic types and their characteristics. Summary of $\mathrm{PhD}$ thesis.- In: Stevanovic Z. \& D. Polomčić (eds.) Hydrogeological research of litosphere in Serbia, Faculty of Mining \& Geology, 185-197, Belgrade.

Lapajne, A., 2006: Izvor in kemijska sestava termalnih in termomineralnih vod v Sloveniji.- Geologija, 49, 2, 347-370.

Law on Environmental Protection, 2004: Official Gazette of the Republic of Serbia, 135/2004, 28-44.

Law on Geologic Investigations, 1995: Official Gazette of the Republic of Serbia, 44/1995, 1625-1629.

Law on Waters, 1991: Official Gazette of the Republic of Serbia, 46/1991, 1827-1841.

Mijatović, B. F. (ed.), 1984: Hydrogeology of the Dinaric Karst.- International contributions to Hydrogeology, Heise Verlag, vol. 4, pp. 255, Hannover.

Mijatović, B., 1997: Aquiferes karstiques de Serbie de louest: La base hydrogeologique de regulation et du controle regime dynamique des eaux souterraines.In: Stevanović, Z. (ed.) 100 years of Hydrogeology in Yugoslavia, Faculty of Mining \& Geology, 187-206, Belgrade.

Milenić, D., 2004: Evaluation of the Groundwater Resources in the Cork City and Harbour Area.- PhD thesis, National University of Ireland, University College Cork. pp. 486.

Milenić, D., 2008: Evaluation of groundwater resources of the municipality of Nova Varos. Report, p. 358, Faculty of Mining \& Geology, Belgrade.
Milenić, D., 2009: Evaluation of groundwater resources of the municipality of Cajetina. Report, p. 314, Faculty of Mining \& Geology, Belgrade.

Milenić, D., Papić, P. \& Dj. Milanković, 2007: Environmental impact of sawmill by-products degradationgroundwater quality case study, Western Serbia.- In: Ribeiro et al. (eds.) Proceedings of the XXXV IAH Congress - Groundwater and ecosystems, 17-21 September 2007, Lisbon, Portugal.

Milivojević, M., Martinović, M. \& M. Simić, 1995: Geothermal resources of Serbia: potentiality, conditions of explorationsuse and some plans for the future.- In: Stevanović, Z. (ed.) Litospheric water mineral resources of Serbia, Faculty of Mining \& Geology, 133-151, Belgrade.

Novak, D., 1992: Tominčev studenec pri dvoru in njegovo zaledje.- Naše jame, 33, 63-73.

Pešić, L., 2002: General geology-endodynamics.- Faculty of Mining \& Geology, pp. 204, Belgrade.

Ravbar, N. \& G. Kovačič, 2006: Karst water management in Slovenia in the frame of vulnerability mapping.Acta carsologica, 35, 2, 73-82.

Ravbar, N. \& N. Goldscheider, 2007: Proposed methodology of vulnerability and contamination risk mapping for the protection of karst aquifers in Slovenia.- Acta carsologica, 36, 3, 397-411.

Regulations of criteria for planning and determination of protection zones of drinking water resources, 2004: Official Gazette of the Republic Slovenia, 64/2004, 8111-8129.

Regulations on determining and maintaining of sanitary protection zones of water supply sources, 2008: Official Gazette of the Republic of Serbia, 92/2008, 1121-1130.

Roglić, J., 1965: The delimitations and morphological types of the Dinaric karst.- Naše jame, 7, 12-20.

Stevanović, Z., 1995: Karst groundwater of Serbia - present and potential uses in regional water supply.- In: Stevanović, Z. (ed.) Litospheric water mineral resources of Serbia, Faculty of Mining \& Geology, 77121, Belgrade.

Stevanović, Z., Filipović, B. \& M. Komatina, 1997: Current state and perspectives of water supply in Yugoslavia by the use of groundwater.- In: Stevanović, Z. (ed.) 100 years of Hydrogeology in Yugoslavia, Faculty of Mining \& Geology, 313-327, Belgrade.

SURS, 2009: Statistical Office of the Republic of Slovenia.- [Online] Available from: http://www.stat.si [Accessed 23 ${ }^{\text {rd }}$ June 2009].

Trček, B., 2007: How can the epikarst zone influence the karst aquifer hydraulic behavior?- Environmental Geology, 51, 5, 761-765.

Waters Act, 2002: Official Gazette of the Republic Slovenia, 67/2002, 7648-7680. 